Article

\title{
An Analysis of Climate Impacts on Herbicide, Insecticide, and Fungicide Expenditures
}

\author{
Lauren A. Rhodes ${ }^{1, *(D)}$ and Bruce A. McCarl ${ }^{2}$ \\ 1 Facultad de Ciencias Sociales y Humanísticas, Escuela Superior Politécnica del Litoral, ESPOL, \\ Guayaquil 090112, Ecuador \\ 2 Department of Agricultural Economics, Texas A\&M University, College Station, TX 77843, USA; \\ mccarl@tamu.edu \\ * Correspondence: rhodes@espol.edu.ec
}

Received: 27 April 2020; Accepted: 19 May 2020; Published: 21 May 2020

\begin{abstract}
The climate alters pest populations and in turn, pesticide use and cost as well as use of other pest treatments. This paper analyzes the effect of the climate on pesticide expenditures by category, namely: fungicides, herbicides, and insecticides. This is done by econometrically estimating the effects of climate variables such as mean temperature and precipitation as well as the number of hot days, cold days, and wet days on the mean and variance of expenditures by category. The estimates are performed for corn, soybeans, spring and winter wheat, and potatoes. We find that climate factors influence fungicide, herbicide, and insecticide expenditures and that this influence is heterogeneous, varying in nature across crops and pesticide categories. Moreover, we find that climate extremes are more important in determining pesticide expenditures than climate averages in several cases.
\end{abstract}

Keywords: pesticides; climate; expenditures; herbicides; insecticides; fungicides; climate extremes

\section{Introduction}

Climate factors have been found to influence pest incidence (pathogens, weeds, fungi, and insects) along with the effectiveness of chemical treatments [1-3]. In turn, changes in the climate have been found to alter pest incidence, abundance, and damages [4-6]. Alterations in damages also cause producers to alter pest control strategies by changing the type, amount, and cost of pesticides as well as the use of pest treatment alternatives [5]. As climate factors have also been found to alter pesticide effectiveness, additional applications and/or alternative compounds are often needed [2].

A number of studies have investigated climate influences on pests, pesticide costs and cost variability [4,6-8]. All review evidence, mainly on insect abundance, showing climate change enhances populations. Chen and McCarl [9] examined the effects of climate change on pesticide expenditures finding that pesticide expenditures rise with increased temperatures and precipitation for the majority of crops. They also found the effects of increased temperature and precipitation on pest treatment cost variability were dependent on the crop. Reilly et al. [10] projected that climate change induced alterations in pesticide expenditures worsen the US effects of climate change by USD 100 million. Additionally, Shakhramanyan, Schneider, and McCarl [11], indicate climate change induced increases in pesticide usage and that this in turn raises external environmental and health costs.

The climate also influences herbicide, insecticide, and fungicide use through changes in their effectiveness and persistence. Lichtenstein and Schulz [12]; Walker and Eagle [13]; Nokes and Young [14]; Garcia-Cazorla and Xirau-Vayreda [15]; Ahmad et al. [16]; Bailey [17] find that increases in temperature can decrease persistence and, in turn, increase the required number of applications. Rainfall amount and intensity can also impact the need for multiple applications by washing the chemicals away [18-22]. Climate changes can increase pest and crop disease incidence as well as crop susceptibility to disease [1]. 
Temperature, precipitation, and humidity are all key factors [1,5,23-25]. Additionally, increased atmospheric $\mathrm{CO}_{2}$ can enhance weed growth $[9,26]$ and increase weed tolerance to herbicides [8].

Some studies indicate that new chemicals may also need to be developed because the crop tolerance to chemicals may be reduced by climate change [27]. However, some cropping practices such as rotating crops and altering cropping dates can lessen the climate change pest effect [28,29].

Warming winter months can also impact pest populations and incidence. Warmer winters can increase the lifespan of disease-causing pathogens [30]. Shorter winters can reduce pathogen and pest die off and increase pest incidence [30]. Additionally, the incidence and severity of a number of crop diseases, fungal infestations, and insects has been found to increase with rising temperatures and increased humidity [31,32].

Previous studies have looked at the effects of climate change on overall pest treatment costs $[9,11,33]$ but have not addressed changes in different components like insecticides, herbicides, and fungicides nor how climate extremes impact these expenditures. This study analyzes the effect of climate variables on average expenditures and their variance for three pesticide subgroups: fungicides, herbicides, and insecticides. Additionally, this study examines how climate extremes, not only climate averages, effect these items in order to have a clearer picture of the future of pesticide use in a changing climate and the influence of extremes.

Economics commonly asserts that usage of an input like pesticides should continue until the marginal costs of using an input equals the marginal benefits obtained when the input is used. In the pesticide case this would mean that the marginal cost of using pesticides should be matched by the marginal damages reduced when they are used. Furthermore, if one postulates that an increase in pest incidence and abundance is correlated with increased damages, then one should see on the margin that as climate change stimulates pests, it should be matched by a corresponding increase in pest treatment efforts seen through changes in expenditures which we estimate in this study. Expenditures on pesticides are used in this study instead of application quantities of compounds as many compounds are substitutes for each other and issues can arise from aggregating compounds of different efficacies. Finally, since climate change affects pest incidence and abundance, this also influences use and may shift compounds, so we choose to use cost as a measure.

Finally, we break cost into insecticides, herbicides, and fungicides to see if the insect, weed or fungus issues are more affected.

\section{Methods and Data}

Here we turn to the estimation of the relationship between the climate and pesticide use by crop and major classes of pesticide (herbicides, insecticides, and fungicides). Since shifts in the climate may cause the need to shift compounds, we estimate the effect in monetary terms. In particular, as argued in Chen and McCarl [9], standard economic reasoning indicates marginal changes in pesticide cost should match up with marginal changes in pest damages. Thus, if the cost of pesticides goes up, this indicates increased pest incidence and associated damages.

In order to estimate the effects of climate variables on pesticide costs by class (fungicides, herbicides, and insecticides), we will utilize the estimation approach advanced in Just and Pope [34] and used within Chen and McCarl [9] among others. The basic structure of the function to be estimated is:

$$
y_{k, i, t}=f_{k}\left(X_{k, i, t}, \alpha\right)+h_{k}\left(X_{k, i . t}, \beta\right) \varepsilon_{k, i, t}
$$

where $y_{k, i, t}$ represents the observed per acre expenditures on pesticide subgroup $k$ in region $i$ during year $t ; X_{k, i, t}$ represents the set of independent variables relevant for this pesticide class, location and time period; $f_{k}\left(X_{k, i, t}, \alpha\right)$ is a function to be estimated that portrays how the independent variables alter mean per acre expenditures on pesticide subgroup $k ; \alpha$ are the parameters within $f_{k}$ to be estimated; $h_{k}\left(X_{k, i . t}, \beta\right) \varepsilon_{k, i, t}$ is a function that portrays how the independent variables alter the variance of the per 
acre expenditures on pesticide subgroup $k ; \beta$ are the parameters to be estimated within the $h$ function and $\varepsilon_{k, i, t}$ is the error term. For an expanded explanation of this approach see McCarl and Rettig [35].

In the estimating equations we include independent variables related to average climate and climate extremes while taking into account year and state fixed effects. For average climate and climate extremes the variables included are: (a) the crop season average temperature; (b) the total level of cropping season precipitation; (c) the number of days with temperatures at or above $90^{\circ} \mathrm{F}$ (about $32.2{ }^{\circ} \mathrm{C}$ ); (d) the number of days with temperatures less than or equal to $32{ }^{\circ} \mathrm{F}\left(0^{\circ} \mathrm{C}\right)$, and (e) the number of days with at least one inch $(2.54 \mathrm{~cm})$ of precipitation. We employ a panel data estimation approach, following Chen, McCarl and Schimmelpfennig [36] and Blanc and Schlenker [37], to pick up systematic regional and temporal characteristics that are not included in our independent variables.

The functions in Equation (1) can be estimated via maximum likelihood or three stage feasible least squares [34]. Both were tried but we had convergence issues with the maximum likelihood approach so we used the three-stage feasible least squares method in iterative form as developed in Buccola and McCarl [38].

Thus, we initially estimate:

$$
y_{k, i, t}=f_{k}\left(X_{k, i, t}, \alpha_{k}^{1}\right)+u_{1 k, i, t}
$$

From this estimation, we get an initial set of errors $u_{1 k, i, t}$, which are potentially heteroskedastic and can be used to estimate the function on variance removing the heteroscedasticity. This is done as follows:

$$
\left|u_{1 k, i, t}\right|=h_{k}\left(X_{k, i, t}, \beta_{k}^{1}\right) \varepsilon_{1 k, i, t}=\beta_{0}^{1} X_{1 k, i, t}^{\beta_{1, k}^{1}} X_{2 k, i, t}^{\beta_{2, k}^{1}} \ldots X_{n k, i, t}^{\beta_{n, k}^{1}} \varepsilon_{1 k ., t}
$$

where we use the absolute values of $u_{1 k, i, t}$ as the dependent variables following Just and Pope [34] and the following functional form for $h$.

This $h$ function can be estimated with ordinary least squares (OLS) and the results show how the variance of pesticide expenditures changes as the independent variables like climate are altered. The estimates of $\alpha^{1}$ from the first round of estimations are consistent but asymptotically inefficient due to the presence of heteroscedasticity (as explained in Just and Pope [34]). In order to obtain consistent and asymptotically efficient estimates of $\alpha$, we follow Just and Pope [34] dividing the terms in Equation (1) through by the $\mathrm{h}$ function evaluated at the values of the independent variables $\left(\hat{h}_{k}\left(X_{k, i, t}, \beta_{k}^{1}\right)\right)$ as follows:

$$
\frac{y_{k, i, t}}{\hat{h}_{k}\left(X_{k, i, t}, \beta_{k}^{1}\right)}=\frac{f_{k}\left(X_{k, i, t}, \alpha_{k}^{2}\right)}{\hat{h}_{k}\left(X_{k, i, t}, \beta_{k}^{1}\right)}+u_{2 k, i, t}
$$

where $u_{2 k, i, t}$ is now a homoscedastic error term. The resulting parameter values are consistent and asymptotically efficient except for the constant term. We also iterate over the steps three times following Buccola and McCarl [38] in all cases excluding estimations for potato insecticides for which two rounds were done and soybean insecticides and potato fungicides for which one round was completed due to the deflating factors becoming excessively large.

The pesticide expenditure data used are constructed by combining pesticide use data with pesticide price information. United States Department of Agriculture (USDA) estimates of application levels by state and compound were drawn from USDA National Agricultural Statistics Service (NASS) Quickstats 2.0 database (Washington, D.C., USA) [39] for 1990 to 2017 as were data on national price indices for fungicides, herbicides, and insecticides relative to 2011 dollars. State level costs per acre data were then computed by multiplying the average national price index for each pesticide type for the year by the corresponding compound application rate. Then, the compound expenditures were added yielding total expenditures within the herbicide, insecticide, and fungicide subgroups. This aggregation to a total cost measure rather than estimating by compound is intended to avoid issues with switching between compounds as time and climate, pest resistance, and other factors evolve.

We drew climate data from a National Oceanic and Atmospheric Administration (NOAA) database (Silver Spring, MD, USA) [40]. These data include monthly precipitation totals (where state level 
data were averaged across all weather stations within that state) over the March through September cropping season and the average March through September cropping season temperature for all crops, except winter wheat where we use October to April. The precipitation data were in inches and the temperatures in degrees Fahrenheit. Additionally, we used daily data to construct growing-season-long counts of the total number of days with temperatures of at least $90^{\circ} \mathrm{F}$ (about $32.2{ }^{\circ} \mathrm{C}$ ), the number of days with temperatures less than or equal to $32^{\circ} \mathrm{F}\left(0^{\circ} \mathrm{C}\right)$, and the number of days with at least one inch $(2.54 \mathrm{~cm})$ of precipitation. Table 1 gives a brief description of the climate variables.

Table 1. Description of climate variables.

\begin{tabular}{cc}
\hline $\begin{array}{c}\text { Climate } \\
\text { Variable }\end{array}$ & Description \\
\hline DT90 & The number of days with temperatures at or above $90^{\circ} \mathrm{F}\left(\right.$ about $\left.32 .{ }^{\circ} \mathrm{C}\right)$ during a cropping period \\
DT32 & The number of days where the minimum temperature is at or below $32{ }^{\circ} \mathrm{F}\left(0{ }^{\circ} \mathrm{C}\right)$ during a \\
cropping period
\end{tabular}

\section{Results}

Equations were estimated for corn, potatoes, soybeans, spring wheat and winter wheat for each pesticide subclass (fungicides, herbicides, and insecticides) for which data were available. In particular, data were available for 12 of the 15 possible cases. For the mean function ( $f$ above) we estimated a polynomial functional form containing both linear and quadratic effects for the climate variables but narrowed the forms based on equation fit and parameter significance. For the variance function we use the log-log model to accommodate the model used. Table 2 shows the results for the 12 cases reflecting the final functional forms chosen.

Table 2. Estimated forms in final estimation for the mean functions.

\begin{tabular}{ccccccc}
\hline Crop & $\begin{array}{c}\text { Pesticide } \\
\text { Subgroup }\end{array}$ & DT90 & DT32 & DP10 & PRCP & TAVG \\
\hline Corn & Herbicides & Linear & Quadratic & Quadratic & Quadratic & Linear \\
Corn & Insecticides & Quadratic & Linear & Linear & Linear & Linear \\
Potatoes & Herbicides & Linear & Quadratic & Linear & Quadratic & Quadratic \\
Potatoes & Insecticides & Linear & Quadratic & Quadratic & Linear & Linear \\
Potatoes & Fungicides & Quadratic & Linear & Quadratic & Linear & Linear \\
Soybeans & Herbicides & Linear & Quadratic & Linear & Linear & Linear \\
Soybeans & Insecticides & Quadratic & Quadratic & Linear & Linear & Quadratic \\
Soybeans & Fungicides & Linear & Quadratic & Linear & Linear & Quadratic \\
Spring Wheat & Herbicides & Linear & Quadratic & Linear & Quadratic & Linear \\
Winter Wheat & Herbicides & Linear & Quadratic & Quadratic & Quadratic & Linear \\
Winter Wheat & Insecticides & Quadratic & Linear & Quadratic & Quadratic & Quadratic \\
Winter Wheat & Fungicides & Quadratic & Linear & Linear & Quadratic & Quadratic \\
\hline
\end{tabular}

Tables 3 and 4 summarize the effects of the climate variables on the mean and variance of pesticide expenditures. Our findings show that climate variables significantly alter pesticide expenditures but not uniformly across crops and pesticide subclasses. Namely, we see some cases where the effects increase expenditures and other cases where they decrease expenditures. This is also true for the effects on the variability of expenditures.

One of the most important findings of this study is that in multiple cases the climate extremes are significant while average temperature and total precipitation are not. This finding implies the importance for future analysis to also consider climate extremes with regard to pesticide expenditures. Furthermore, the number of days with temperatures at or below $32^{\circ} \mathrm{F}\left(0^{\circ} \mathrm{C}\right)$ has a quadratic effect 
on mean expenditures (increasing in the linear term and decreasing in the quadratic term) for most crops. This quadratic effect may occur because only a few days of cold temperatures might signify optimal conditions for pests, but as extreme cold conditions increase, pest incidence and damages are reduced (as argued in (Wollenweber, Porter, and Schellberg [41]). Additionally, this may occur because at the turning point, decreases in yields resulting from the climatic conditions may make it no longer profitable to continue adding pesticides. The number of hot, $90^{\circ} \mathrm{F}$ (about $32.2^{\circ} \mathrm{C}$ ) plus, days has primarily positive effects on mean expenditures potentially due to better conditions for the pest populations, however this effect is not seen for all crop pesticide subclass combinations. Despite this, in most significant cases, the average temperature has a negative effect on pesticide expenditures.

Table 3. Summary of climate effects for the mean of pesticide expenditures.

\begin{tabular}{cccccc}
\hline Crop and Pesticide & DT90 & DT32 & DP10 & PRCP & TAVG \\
\hline Corn Herbicide & - & ${ }^{*} \mathrm{Q}-$ & $+{ }^{*} \mathrm{Q}-$ & $-\mathrm{Q}+$ & + \\
Corn Insecticide & $-\mathrm{Q}+^{*}$ & - & + & - & + \\
Potatoes Herbicide & $+{ }^{*}$ & $+\mathrm{Q}-$ & $+^{*}$ & $-\mathrm{Q}+$ & $+\mathrm{Q}-$ \\
Potatoes Insecticide & $+{ }^{*}$ & $+{ }^{*} \mathrm{Q}-$ & $+\mathrm{Q}-$ & - & $-{ }^{*}$ \\
Potatoes Fungicide & $+\mathrm{Q}-$ & - & $+\mathrm{Q}-$ & + & - \\
Soybeans Herbicide & - & $+\mathrm{Q}-$ & - & + & + \\
Soybeans Insecticide & $+\mathrm{Q}-{ }^{*}$ & $+{ }^{*} \mathrm{Q}-{ }^{*}$ & - & - & $-\mathrm{Q}+{ }^{*}$ \\
Soybeans Fungicide & + & $+{ }^{*} \mathrm{Q}-{ }^{*}$ & $-{ }^{*}$ & + & $-\mathrm{Q}+$ \\
Spring Wheat Herbicide & + & $-\mathrm{Q}+$ & - & $+\mathrm{Q}+$ & + \\
Winter Wheat Herbicide & $+{ }^{*}$ & $+{ }^{*} \mathrm{Q}-{ }^{*}$ & $-\mathrm{Q}+$ & $+\mathrm{Q}-{ }^{*}$ & $-{ }^{*}$ \\
Winter Wheat Insecticide & $-{ }^{*} \mathrm{Q}+$ & + & $-{ }^{*} \mathrm{Q}+{ }^{*}$ & $+{ }^{*} \mathrm{Q}-{ }^{*}$ & $-\mathrm{Q}+$ \\
Winter Wheat Fungicide & $-\mathrm{Q}+$ & - & - & $+{ }^{*} \mathrm{Q}-{ }^{*}$ & $+\mathrm{Q}-$ \\
\hline
\end{tabular}

Here "-" denotes a negative effect (decrease in expenditures), "+" a positive effect (increase in expenditures), " $-Q+$ " a quadratic effect that is initially decreasing then increasing, "+ $Q-$ " a quadratic effect that is initially increasing then decreasing, and " $-\mathrm{Q}-$ " a quadratic effect that is decreasing at a decreasing rate. $\mathrm{A}$ " $*$ " indicates findings significant at least at the $10 \%$ level.

Table 4. Summary of climate effects for the variance of pesticide expenditures.

\begin{tabular}{cccccc}
\hline Crop and Pesticides & DT90 & DT32 & DP10 & PRCP & TAVG \\
\hline Corn Herbicide & - & - & + & - & + \\
Corn Insecticide & - & - & + & - & + \\
Potatoes Herbicide & - & - & - & + & + \\
Potatoes Insecticide & + & + & $+^{*}$ & $-^{*}$ & + \\
Potatoes Fungicide & $-{ }^{*}$ & + & - & + & + \\
Soybeans Herbicide & + & + & + & + & - \\
Soybeans Insecticide & - & - & + & - & + \\
Soybeans Fungicide & - & - & + & - & - \\
Spring Wheat Herbicide & + & - & - & + & + \\
Winter Wheat Herbicide & $+^{*}$ & $+^{*}$ & $+^{*}$ & $-*$ & $-^{*}$ \\
Winter Wheat Insecticide & - & - & + & + & - \\
Winter Wheat Fungicide & - & + & - & + & $+^{*}$ \\
\hline
\end{tabular}

Here " -" denotes a negative effect (decrease in expenditures) and "+" a positive effect (increase in expenditures). $\mathrm{A}$ "** indicates findings significant at least at the $10 \%$ level.

We also find that the number of days with at least one inch $(2.54 \mathrm{~cm})$ of precipitation has a mixed effect on mean expenditures depending on the crop and pesticide subclass while total cumulative precipitation has a quadratic effect (increasing in the linear term and decreasing in the quadratic term) in many of the significant cases. This could be due to better habitat conditions for various types of pests with some rainfall, but large amounts may either cause the main crop to grow and overshadow the weeds (thus creating less need for herbicides) or flood out undesirable plants and insects also reducing the need for pesticides. 
The following sections discuss these effects in greater detail by crop and class. The estimated effects on mean expenditures are provided in Tables 5-7, and the estimated effects on the variance in expenditures are provided in Tables 8-10.

Table 5. Estimated effects on mean pesticide expenditures for corn and potatoes.

\begin{tabular}{|c|c|c|c|c|c|}
\hline & $\begin{array}{c}\text { Corn } \\
\text { Herbicide }\end{array}$ & $\begin{array}{c}\text { Corn } \\
\text { Insecticide }\end{array}$ & $\begin{array}{l}\text { Potatoes } \\
\text { Herbicide }\end{array}$ & $\begin{array}{l}\text { Potatoes } \\
\text { Insecticide }\end{array}$ & $\begin{array}{l}\text { Potatoes } \\
\text { Fungicide }\end{array}$ \\
\hline Adj. $R^{2}$ & 0.625 & 0.424 & 0.465 & 0.397 & 0.524 \\
\hline DT90 & $\begin{array}{l}-2.793 \\
(2.328)\end{array}$ & $\begin{array}{l}-0.614 \\
(0.595)\end{array}$ & $\begin{array}{l}14.65^{* *} \\
(5.555)\end{array}$ & $\begin{array}{c}63.00^{* * *} \\
(16.02)\end{array}$ & $\begin{array}{l}57.06 \\
(34.15)\end{array}$ \\
\hline DT90² & & $\begin{array}{l}0.0128^{* * *} \\
(0.00431)\end{array}$ & & & $\begin{array}{l}-1.495 \\
(1.028)\end{array}$ \\
\hline DT32 & $\begin{array}{l}17.87^{* *} \\
(6.653)\end{array}$ & $\begin{array}{l}-0.165 \\
(1.903)\end{array}$ & $\begin{array}{c}5.272 \\
(15.89)\end{array}$ & $\begin{array}{l}46.42 * \\
(23.27)\end{array}$ & $\begin{array}{l}-7.481 \\
(9.270)\end{array}$ \\
\hline${\text { DT } 32^{2}}^{2}$ & $\begin{array}{l}-0.265 \\
(0.155)\end{array}$ & & $\begin{array}{c}-0.0442 \\
(0.162)\end{array}$ & $\begin{array}{l}-0.383 \\
(0.260)\end{array}$ & \\
\hline DP10 & $\begin{array}{l}70.30^{*} \\
(37.03)\end{array}$ & $\begin{array}{c}1.874 \\
(4.025)\end{array}$ & $\begin{array}{l}7.924 * \\
(3.747)\end{array}$ & $\begin{array}{c}65.21 \\
(46.97)\end{array}$ & $\begin{array}{l}83.38 \\
(58.49)\end{array}$ \\
\hline DP10 2 & $\begin{array}{l}-0.780 \\
(0.611)\end{array}$ & & & $\begin{array}{l}-0.398 \\
(0.532)\end{array}$ & $\begin{array}{l}-0.789 \\
(0.640)\end{array}$ \\
\hline PRCP & $\begin{array}{l}-63.99 \\
(72.50)\end{array}$ & $\begin{array}{l}-1.218 \\
(3.913)\end{array}$ & $\begin{array}{l}-19.61 \\
(18.89)\end{array}$ & $\begin{array}{l}-18.58 \\
(23.67)\end{array}$ & $\begin{array}{l}1.762 \\
(22.39)\end{array}$ \\
\hline $\mathrm{PRCP}^{2}$ & $\begin{array}{l}1.209 \\
(1.644)\end{array}$ & & $\begin{array}{c}0.176 \\
(0.383)\end{array}$ & & \\
\hline TAVG & $\begin{array}{c}5.204 \\
(7.248)\end{array}$ & $\begin{array}{l}2.097 \\
(2.371)\end{array}$ & $\begin{array}{c}28.52 \\
(22.33)\end{array}$ & $\begin{array}{l}-47.86^{* *} \\
(21.65)\end{array}$ & $\begin{array}{l}-41.10 \\
(59.99)\end{array}$ \\
\hline TAVG $^{2}$ & & & $\begin{array}{l}-0.396 \\
(0.281)\end{array}$ & & \\
\hline
\end{tabular}

Values in parenthesis are standard errors. ${ }^{* * *}$ implies $p$-value $\leq 0.01 ;{ }^{* *}$ implies $p$-value $\leq 0.05 ;{ }^{*}$ implies $p$-value $\leq 0.1$. The estimates were performed using degrees Fahrenheit for TAVG and TAVG ${ }^{2}$ and inches for PRCP and PRCP ${ }^{2}$.

Table 6. Estimated effects on mean pesticide expenditures for soybeans and spring wheat.

\begin{tabular}{|c|c|c|c|c|}
\hline & $\begin{array}{l}\text { Soybeans } \\
\text { Herbicide }\end{array}$ & $\begin{array}{l}\text { Soybeans } \\
\text { Insecticide }\end{array}$ & $\begin{array}{l}\text { Soybeans } \\
\text { Fungicide }\end{array}$ & $\begin{array}{l}\text { Spring Wheat } \\
\text { Herbicide }\end{array}$ \\
\hline Adj. $R^{2}$ & 0.708 & 0.351 & 0.566 & 0.293 \\
\hline DT90 & $\begin{array}{l}-2.559 \\
(3.266)\end{array}$ & $\begin{array}{c}0.912 \\
(1.707)\end{array}$ & $\begin{array}{c}0.174 \\
(0.305)\end{array}$ & $\begin{array}{c}3.340 \\
(1.876)\end{array}$ \\
\hline DT90 2 & & $\begin{array}{c}-0.0274^{* *} \\
(0.0116)\end{array}$ & & \\
\hline DT32 & $\begin{array}{c}5.870 \\
(8.211)\end{array}$ & $\begin{array}{l}6.717 * \\
(3.264)\end{array}$ & $\begin{array}{l}3.430 * * \\
(1.592)\end{array}$ & $\begin{array}{l}-7.407 \\
(27.55)\end{array}$ \\
\hline DT32 ${ }^{2}$ & $\begin{array}{c}-0.0377 \\
(0.115)\end{array}$ & $\begin{array}{c}-0.0580 * * \\
(0.0241)\end{array}$ & $\begin{array}{c}-0.0395^{* *} \\
(0.0176)\end{array}$ & $\begin{array}{l}0.0134 \\
(0.224)\end{array}$ \\
\hline DP10 & $\begin{array}{l}-3.649 \\
(5.930)\end{array}$ & $\begin{array}{l}-0.796 \\
(1.327)\end{array}$ & $\begin{array}{c}-1.842 * \\
(0.891)\end{array}$ & $\begin{array}{l}-19.34 \\
(12.75)\end{array}$ \\
\hline DP10 2 & & & & \\
\hline PRCP & $\begin{array}{c}5.273 \\
(6.048)\end{array}$ & $\begin{array}{l}-1.687 \\
(1.605)\end{array}$ & $\begin{array}{c}1.215 \\
(1.420)\end{array}$ & $\begin{array}{c}10.84 \\
(41.57)\end{array}$ \\
\hline PRCP $^{2}$ & & & & $\begin{array}{c}1.003 \\
(0.880)\end{array}$ \\
\hline TAVG & $\begin{array}{c}6.511 \\
(6.339)\end{array}$ & $\begin{array}{l}-94.42 \\
(59.33)\end{array}$ & $\begin{array}{l}-2.201 \\
(3.649)\end{array}$ & $\begin{array}{c}21.00 \\
(15.90)\end{array}$ \\
\hline TAVG $^{2}$ & & $\begin{array}{l}0.929 * \\
(0.493)\end{array}$ & $\begin{array}{c}0.0417 \\
(0.0495)\end{array}$ & \\
\hline
\end{tabular}

Values in parenthesis are standard errors. ${ }^{* *}$ implies $p$-value $\leq 0.05 ;{ }^{*}$ implies $p$-value $\leq 0.1$. The estimates were performed using degrees Fahrenheit for TAVG and TAVG ${ }^{2}$ and inches for PRCP and PRCP ${ }^{2}$. 
Table 7. Estimated effects on mean pesticide expenditures for winter wheat.

\begin{tabular}{cccc}
\hline & $\begin{array}{c}\text { Winter Wheat } \\
\text { Herbicide }\end{array}$ & $\begin{array}{c}\text { Winter Wheat } \\
\text { Insecticide }\end{array}$ & $\begin{array}{c}\text { Winter Wheat } \\
\text { Fungicide }\end{array}$ \\
\hline Adj. $\mathbf{R}^{2}$ & 0.655 & 0.612 & 0.737 \\
DT90 & $25.61^{* * *}$ & $-10.55^{* * *}$ & -0.772 \\
& $(4.144)$ & $(3.052)$ & $(5.287)$ \\
DT90 & & 0.317 & 0.0282 \\
& & $(0.320)$ & $(0.245)$ \\
DT32 & $53.45^{* * *}$ & 0.444 & -0.00917 \\
& $(14.42)$ & $(0.348)$ & $(0.133)$ \\
DT32 & $-0.538^{* *}$ & & \\
& $(0.226)$ & & \\
DP10 & -168.2 & $-2.954^{* * *}$ & -0.420 \\
& $(133.8)$ & $(0.762)$ & $(0.305)$ \\
DP10 & 3.900 & $0.0193 * * *$ & \\
& $(2.411)$ & $(0.00565)$ & \\
PRCP $^{2}$ & 206.3 & $4.0323^{* *}$ & $3.174 * * *$ \\
& $(137.4)$ & $(1.616)$ & $(0.780)$ \\
PRCP $^{2}$ & $-6.750 *$ & $-0.0489 * *$ & $-0.0309 * * *$ \\
& $(3.372)$ & $(0.0185)$ & $(0.0108)$ \\
TAVG $^{*}$ & $-17.59^{* * *}$ & -3.300 & 0.473 \\
& $(5.022)$ & $(4.439)$ & $(2.321)$ \\
TAVG $^{2}$ & & 0.0741 & -0.0202 \\
& & $(0.0761)$ & $(0.0458)$ \\
\hline
\end{tabular}

Values in parenthesis are standard errors. ${ }^{* * *}$ implies $p$-value $\leq 0.01$; ${ }^{* *}$ implies $p$-value $\leq 0.05$; ${ }^{*}$ implies $p$-value $\leq 0.1$. The estimates were performed using degrees Fahrenheit for TAVG and TAVG ${ }^{2}$ and inches for PRCP and PRCP ${ }^{2}$.

Table 8. Estimated effects on variance of pesticide expenditures for corn and potatoes.

\begin{tabular}{cccccc}
\hline & $\begin{array}{c}\text { Corn } \\
\text { Herbicide }\end{array}$ & $\begin{array}{c}\text { Corn } \\
\text { Insecticide }\end{array}$ & $\begin{array}{c}\text { Potatoes } \\
\text { Herbicide }\end{array}$ & $\begin{array}{c}\text { Potatoes } \\
\text { Insecticide }\end{array}$ & $\begin{array}{c}\text { Potatoes } \\
\text { Fungicide }\end{array}$ \\
\hline Adj. R & 0.249 & 0.112 & 0.031 & 0.184 & 0.026 \\
Ln(DT90) & -0.0435 & -0.147 & -0.439 & 0.209 & $-0.456^{*}$ \\
& $(0.922)$ & $(1.108)$ & $(0.276)$ & $(0.121)$ & $(0.209)$ \\
Ln(DT32) & -0.984 & -0.0944 & -0.414 & 0.663 & 0.755 \\
& $(3.496)$ & $(0.460)$ & $(0.489)$ & $(0.743)$ & $(1.214)$ \\
Ln(DP10) & 1.742 & 0.891 & -0.765 & $3.585^{* * *}$ & -0.321 \\
& $(4.295)$ & $(1.048)$ & $(2.370)$ & $(0.881)$ & $(2.106)$ \\
Ln(PRCP) & -1.785 & -0.645 & 0.00134 & $-2.683^{* * *}$ & 0.708 \\
& $(1.673)$ & $(1.449)$ & $(1.556)$ & $(0.677)$ & $(1.097)$ \\
Ln(TAVG) & 0.745 & 1.166 & 1.050 & 2.737 & 9.073 \\
& $(3.966)$ & $(5.971)$ & $(1.076)$ & $(5.504)$ & $(9.366)$ \\
\hline
\end{tabular}

Values in parenthesis are standard errors. ${ }^{* * *}$ implies $p$-value $\leq 0.01 ;{ }^{*}$ implies $p$-value $\leq 0.1$. The estimates were performed using degrees Fahrenheit for TAVG and TAVG ${ }^{2}$ and inches for PRCP and PRCP 2 .

Table 9. Estimated effects on variance of pesticide expenditures for soybeans and spring wheat.

\begin{tabular}{ccccc}
\hline & $\begin{array}{c}\text { Soybeans } \\
\text { Herbicide }\end{array}$ & $\begin{array}{c}\text { Soybeans } \\
\text { Insecticide }\end{array}$ & $\begin{array}{c}\text { Soybeans } \\
\text { Fungicide }\end{array}$ & $\begin{array}{c}\text { Spring Wheat } \\
\text { Herbicide }\end{array}$ \\
\hline Adj. $R^{2}$ & 0.106 & Approx. 0 & 0.007 & Approx. 0 \\
Ln(DT90) & 250.0 & -0.679 & -0.283 & 0.0549 \\
& $(205.3)$ & $(0.600)$ & $(1.688)$ & $(0.335)$ \\
Ln(DT32) & 255.4 & -0.0154 & -0.0280 & -2.091 \\
& $(209.3)$ & $(0.247)$ & $(1.559)$ & $(3.215)$ \\
Ln(DP10) & 1942 & 2.574 & 4.105 & -5.168 \\
& $(1589)$ & $(2.290)$ & $(4.618)$ & $(3.995)$ \\
Ln(PRCP) & 76.23 & -1.920 & -4.133 & 4.642 \\
& $(64.66)$ & $(1.425)$ & $(4.380)$ & $(3.666)$ \\
Ln(TAVG) & -3645 & 15.61 & -4.290 & 4.979 \\
& $(2987)$ & $(9.184)$ & $(7.438)$ & $(4.987)$ \\
\hline
\end{tabular}

Values in parenthesis are standard errors. The estimates were performed using degrees Fahrenheit for TAVG and $\mathrm{TAVG}^{2}$ and inches for PRCP and PRCP 2 . 
Table 10. Estimated effects on variance of pesticide expenditures for winter wheat.

\begin{tabular}{cccc}
\hline & $\begin{array}{c}\text { Winter Wheat } \\
\text { Herbicide }\end{array}$ & $\begin{array}{c}\text { Winter Wheat } \\
\text { Insecticide }\end{array}$ & $\begin{array}{c}\text { Winter Wheat } \\
\text { Fungicide }\end{array}$ \\
\hline Adj. $\mathrm{R}^{2}$ & 0.419 & Approx. 0 & Approx. 0 \\
Ln(DT90) & $0.0444^{*}$ & -0.0216 & -0.108 \\
& $(0.0230)$ & $(0.0962)$ & $(0.0777)$ \\
Ln(DT32) & $11.65^{* * *}$ & -0.404 & 0.983 \\
& $(3.464)$ & $(1.142)$ & $(0.916)$ \\
Ln(DP10) & $8.163^{* * *}$ & 0.305 & -1.966 \\
& $(2.138)$ & $(2.552)$ & $(2.454)$ \\
Ln(PRCP) & $-7.750^{* * *}$ & 0.323 & 0.287 \\
& $(2.118)$ & $(2.508)$ & $(1.698)$ \\
Ln(TAVG) & $-22.2^{* * *}$ & -0.771 & $2.277^{*}$ \\
& $(6.457)$ & $(1.553)$ & $(1.261)$ \\
\hline
\end{tabular}

Values in parenthesis are standard errors. ${ }^{* * *}$ implies $p$-value $\leq 0.01 ;{ }^{*}$ implies $p$-value $\leq 0.1$. The estimates were performed using degrees Fahrenheit for TAVG and TAVG ${ }^{2}$ and inches for PRCP and PRCP ${ }^{2}$.

\subsection{Effects on Corn Pesticides}

Expenditures on pesticides for corn are mainly influenced by climate extremes. The number of days with temperatures at or below $32^{\circ} \mathrm{F}\left(0^{\circ} \mathrm{C}\right)$ and the number of days with at least one inch $(2.54 \mathrm{~cm})$ of precipitation have significant quadratic relationships with herbicide expenditures. Both increase expenditures up to thresholds of 33.7 and 45.1 days, respectively, at which point their effect becomes negative. For heavy rainfall days, the average number of days across the US is below 45 days implying that in many cases, we should expect a positive marginal relationship. This is likely due to increased chemical washoff from stronger instances of rainfall. Interestingly, total precipitation is not significantly related to expenditures in this particular case. The average number of cold days across the US is close to the turning point for the effect on expenditures, so it is unclear which sign the marginal effect will take in most cases but it will rather be location specific.

Similarly, the number of days with temperatures of at least $90{ }^{\circ} \mathrm{F}$ (about $32.2^{\circ} \mathrm{C}$ ) has a significant quadratic relationship with insecticide expenditures. The marginal effect is negative up to approximately 24 days at which point it becomes positive. On average there are approximately 29 hot days in the US during the growing season for corn implying positive marginal effects in most cases. Ziska and McConnell [8] found that rising temperatures lead to the expansion of some insect types which may account for the relationship found here. No other variables had a significant effect on expenditures in either subgroup nor on the variance of expenditures.

Data were not available to estimate a function for use of fungicides on corn.

\subsection{Potato Pesticide Expenditures}

All climate variables have a significant effect on average pesticide expenditures for potatoes. Herbicide and insecticide expenditures are both positively related to the number of $90^{\circ} \mathrm{F}$ (about $32.2^{\circ} \mathrm{C}$ ) plus days with an expected increase of $3.7 \%$ per additional day for herbicide and an expected increase of $9.41 \%$ for insecticide expenditures. However, insecticide expenditures are negatively related to the average temperature with an expected $7.15 \%$ decrease in expenditures with a one-degree Fahrenheit (approximately $0.556{ }^{\circ} \mathrm{C}$ ) increase in average temperature. Therefore, when examining expected effects from climate change, both measures will need to be examined in the context of each other as they have competing effects. Additionally, increases in the number of hot days have a negative effect on the variance of expenditures on fungicides. This is potentially due to an unfavorable climate for fungal growth at high temperatures [42].

While increases in the number of hot days are expected to increase insecticide expenditures, increases in the number of cold days are also expected to increase these expenditures in many cases. The number of $32{ }^{\circ} \mathrm{F}\left(0^{\circ} \mathrm{C}\right)$ or less days has a quadratic relationship with insecticide expenditures and 
are expected to increase expenditures up to about 60.6 days at which point the relationship becomes negative, potentially due to economic as well as biological reasons. As the mean number of days is 48.06, we expect a positive relationship in most observed cases.

The number of days with at least one inch $(2.54 \mathrm{~cm})$ of precipitation has a positive effect on the variance of insecticide expenditures, while the total precipitation has a negative effect. This difference in effects could be attributed to increased washoff occurring on the days of heavier rainfall as suggested by Mayo [43] for the case of corn. Farmers likely make application decisions with forecasts of total rainfall but are unaware when increased washoff might occur. Additionally, a one day increase in the number of heavy rainfall days is expected to increase herbicide expenditures by about $2 \%$. Climate variables not discussed in this section for a given subclass of pesticides did not have significant effects on expenditures.

\subsection{Soybean Pesticide Effects}

Average expenditures on soybean insecticides are significantly impacted by the average cropping year temperature and the number of hot and cold days. Both climate factors associated with extreme temperatures have initial positive relationships but with quadratic effects. Expenditures on insecticides increase until the number of hot days reaches 16.64 and until the number of cold days reaches 57.91 and then decreases thereafter. Given that, on average, the states growing soybeans have approximately 42 hot days and 19 cold days, we can expect that in the majority of cases an increase in the number of hot days will have a negative effect, and the number of cold days will have a positive effect. This quadratic relationship for the number of cold days also holds for fungicide expenditures with the relationship being positive up until there are approximately 43.4 days with temperatures at or below $32{ }^{\circ} \mathrm{F}\left(0^{\circ} \mathrm{C}\right)$. Expenditures on soybean insecticides also have a quadratic relationship with the mean temperatures. The effect is expected to be negative up to an average of $50.82^{\circ} \mathrm{F}$ (about $10.46^{\circ} \mathrm{C}$ ) at which point the effect is positive.

Unlike many of the other crops, none of the climate variables have effects on herbicide expenditures for soybeans. Additionally, the variance in expenditures in all pesticide subclasses for soybean production are not significantly influenced by the climate variables.

\subsection{Spring and Winter Wheat Expenditures}

Expenditures on herbicides used for winter wheat are significantly influenced by all climate variables examined either affecting the mean or variance of expenditures. While a marginal increase in the number of $90^{\circ} \mathrm{F}$ (about $32.2^{\circ} \mathrm{C}$ ) plus days is expected to increase mean herbicide expenditures by $16.81 \%$, a marginal increase in the average temperature (about $0.556^{\circ} \mathrm{C}$ ) is expected to decrease expenditures on herbicides by $11.55 \%$. Therefore, any estimates when considering climate change scenarios will need to consider which effect will likely dominate. Additionally, the number of cold $32^{\circ} \mathrm{F}$ $\left(0{ }^{\circ} \mathrm{C}\right)$ or less days have a quadratic relationship with herbicide expenditures with this climate variable expected to have a positive marginal effect up to approximately 49.7 cold days and negative thereafter. This climate variable also has a positive effect on the variance of expenditures for herbicides which is supported by increases in the average temperature decreasing variability. Like potato insecticide expenditures, the variance in expenditures is positively related to the number of days with at least one inch $(2.54 \mathrm{~cm})$ of precipitation and negatively related to the total precipitation likely due to application decisions given uncertainty about chemical washoff. Finally, the total precipitation is expected to increase herbicide expenditures until the total precipitation is approximately 15.28 inches (about $38.81 \mathrm{~cm}$ ).

The number of hot days, the number of days with at least one inch $(2.54 \mathrm{~cm})$ of precipitation and the total precipitation all have quadratic relationships with expenditures on insecticides for winter wheat. A marginal increase in the number of hot days and the number of rainy days is expected to decrease expenditures if the number of days is below 15.28 and 76.53, respectively. As the average number of days for these two variables during the winter wheat cropping season in the states growing 
winter wheat are 1.83 and 34.96, we expect that the majority of the marginal effect will be negative for the hot days, but it will be highly location dependent for the effects from the number of rainy days. Additionally, the marginal effect of total precipitation is expected to be negative for total precipitation below 41.18 inches (about $104.6 \mathrm{~cm}$ ).

Similarly, the marginal effect of total precipitation for fungicide expenditures is expected to be negative for total precipitation below 51.36 inches (about $130.45 \mathrm{~cm}$ ). Moreover, the variance in fungicide expenditures is expected to increase with higher average temperatures. This could potentially be due to better conditions for crop diseases occurring in some areas [1].

No climate variables have significant effects on spring wheat herbicide expenditures, nor were sufficient data available to estimate functions for use of insecticides or fungicides on spring wheat.

\section{Discussion and Conclusions}

We examine the consequences of changes in climate on pesticide expenditures for fungicides, herbicides, and insecticides. We find that climate variables have a significant effect on usage although the exact nature of the impact depends upon crop, pesticide subclass, and in some cases current climate characteristics.

In terms of climate impacts on mean expenditures, we find that it is climate extremes, not only the typically thought of total precipitation and average temperature, that have significant effects on pesticide expenditures. As we see climate extremes increase, we can generally expect increases in expenditures, though this varies by crop, pesticide subclass, and location. Our findings imply that future studies should pay close attention to climate extremes and also consider the relative strength of effects from competing climate variables as we find cases where increases in extreme temperature, for instance, have a different effect than increases in the average temperature. Additionally, the climate variables have a crop, pesticide subclass, and location-specific effect on variance in expenditures, but in many cases the effect is insignificant. However, every climate variable has a significant effect on the variance for winter wheat herbicide expenditures (with the climate extremes increasing it, the average temperature and total precipitation decreasing it) implying that planting this crop might become less desirable if future climate change involves more extremes. However, decision makers will need to consider the strength of effects for competing variables (such as total precipitation and heavy rainfall days). It would be beneficial for this body of work if future studies utilize disaggregated data to study these effects for specific locations.

Alterations in future pesticide expenditures will depend upon the degree to which certain climate factors change relative to other climate factors. For instance, in the case of herbicide applications for winter wheat, the average temperature over the cropping year and the number of $90{ }^{\circ} \mathrm{F}$ (about $32.2{ }^{\circ} \mathrm{C}$ ) or more days have opposite effects on the mean level of expenditures, so future trends in these expenditures will be dependent on their relative changes. Future research could evaluate these changes in expenditures under climate scenarios and other non-chemical pest management practices to obtain a more holistic view of expected changes in pest management.

Author Contributions: Conceptualization, B.A.M.; methodology, B.A.M. and L.A.R.; software, L.A.R.; validation, L.A.R.; formal analysis, L.A.R.; investigation, L.A.R.; resources, B.A.M. and L.A.R.; data curation, L.A.R.; writing-original draft preparation, L.A.R.; writing-review and editing, B.A.M.; visualization, L.A.R.; supervision, B.A.M.; project administration, L.A.R.; funding acquisition, B.A.M. All authors have read and agreed to the published version of the manuscript.

Funding: This research was partially funded by the U.S. Department of Agriculture-National Institute of Food and Agriculture under grant 2011-67003-30213 in the NSF-USDA-DOE Earth System Modelling Program, and by the NOAA-Climate Programs Office-Sectoral Applications Research Program under grant NA12OAR4310097.

Conflicts of Interest: The funders had no role in the design of the study; in the collection, analyses, or interpretation of data; in the writing of the manuscript, or in the decision to publish the results. The authors declare no conflict of interest. 


\section{References}

1. Van Maanen, A.; Xu, X.-M. Modelling plant disease epidemics. Eur. J. Plant Pathol. 2003, 109, 669-682. [CrossRef]

2. Bloomfield, J.P.; Williams, R.J.; Gooddy, D.C.; Cape, J.N.; Guha, P.M. Impacts of climate change on the fate and behaviour of pesticides in surface and groundwater-A UK perspective. Sci. Total Environ. 2006, 369, 163-177. [CrossRef] [PubMed]

3. Matzrafi, M. Climate change exacerbates pest damage through reduced pesticide efficacy. Pest Manag. Sci. 2019, 75, 9-13. [CrossRef] [PubMed]

4. Deutch, C.A.; Tewksbury, J.J.; Huey, R.B.; Sheldon, K.S.; Ghalambor, C.K.; Haak, D.C.; Martin, P.R. Impacts of climate warming on terrestrial ectotherms across latitude. Proc. Natl. Acad. Sci. USA 2008, 105, 6668-6672. [CrossRef] [PubMed]

5. Ladányi, M.; Horváth, L. A review of the potential climate change impact on insect populations- General and agricultural aspects. Appl. Ecol. Environ. Res. 2010, 8, 143-152. [CrossRef]

6. Poggi, S.; Le Cointe, R.; Riou, J.B.; Larroudé, P.; Thibord, J.B.; Plantegenest, M. Relative influence of climate and agroenvironmental factors on wireworm damage risk in maize crops. J. Pest Sci. 2018, 91, 585-599. [CrossRef]

7. Ziska, L.H.; Blumenthal, D.M.; Runion, G.B.; Hunt, E.R.; Diaz-Soltero, H. Invasive species and climate change: An agronomic perspective. Clim. Chang. 2011, 105, 13-42. [CrossRef]

8. Ziska, L.H.; McConnell, L.L. Climate change, carbon dioxide, and pest biology: Monitor, mitigate, manage. J. Agric. Food Chem. 2016, 64, 6-12. [CrossRef]

9. Chen, C.-C.; McCarl, B.A. An investigation of the relationship between pesticide usage and climate change. Clim. Chang. 2001, 50, 475-487. [CrossRef]

10. Reilly, J.; Tubiello, F.; McCarl, B.A.; Abler, D.; Darwin, R.; Fuglie, K.; Hollinger, S.; Izaurralde, C.; Jagtap, S.; Jones, J.; et al. US agriculture and climate change: New results. Clim. Chang. 2003, 57, 43-67. [CrossRef]

11. Shakhramanyan, N.G.; Schneider, U.A.; McCarl, B.A. Pesticide and greenhouse gas externalities from US agriculture-The impact of their internalization and climate change. Clim. Chang. Econ. 2013, 4, 1350008. [CrossRef]

12. Lichtenstein, E.P.; Schulz, K.R. Persistence of some chlorinated hydrocarbon insecticides as influenced by soil types, rate of application and temperature. J. Econ. Entomol. 1959, 52, 124-131. [CrossRef]

13. Walker, A.; Eagle, D.J. Prediction of herbicide residues in soil for advisory purposes. Asp. Appl. Biol. 1983, 4, 503-509.

14. Nokes, S.E.; Young, J.H. Predicting the persistence and efficacy of chlorothalonil on peanut leafspot. Trans. ASAE 1992, 35, 1699-1708. [CrossRef]

15. Garcia-Cazorla, J.; Xirau-Vayreda, M. Persistence of dicarboximidic fungicide residues in grapes, must, and wine. Am. J. Enol. Vitic. 1994, 45, 338-340.

16. Ahmad, R.; James, T.K.; Rahman, A.; Holland, P.T. Dissipation of the herbicide clopyralid in an allophanic soil: Laboratory and field studies. J. Environ. Sci. Health 2003, 38, 683-695. [CrossRef]

17. Bailey, S.W. Climate change and decreasing herbicide persistence. Pest Manag. Sci. Former. Pestic. Sci. 2004, 60, 158-162. [CrossRef]

18. Cabras, P.; Angioni, A.; Garau, V.L.; Melis, M.; Pirisi, F.M.; Cabitza, F.; Pala, M. The effect of simulated rain on folpet and mancozeb residues on grapes and on vine leaves. J. Environ. Sci. Health Part B 2001, 36, 609-618. [CrossRef]

19. McDowell, L.L.; Willis, G.H.; Southwick, L.M.; Smith, S. Methyl parathion and EPN washoff from cotton plants by simulated rainfall. Environ. Sci. Technol. 1984, 18, 423-427. [CrossRef]

20. Pick, F.E.; Van Dyk, L.P.; De Beer, P.R. The effect of simulated rain on deposits of some cotton pesticides. Pestic. Sci. 1984, 15, 616-623. [CrossRef]

21. McDowell, L.L.; Willis, G.H.; Southwick, L.M.; Smith, S., Jr. Fenvalerate wash-off from cotton plants by rainfall. Pestic. Sci. 1987, 21, 83-92. [CrossRef]

22. Willis, G.H.; Smith, S.; McDowell, L.L.; Southwick, L.M. Carbaryl washoff from soybean plants. Arch. Environ. Contam. Toxicol. 1996, 31, 239-243. [CrossRef] [PubMed]

23. Porter, J.H.; Parry, M.L.; Carter, T.R. The potential effects of climatic change on agricultural insect pests. Agric. For. Meteorol. 1991, 57, 221-240. [CrossRef] 
24. Cannon, R.J.C. The implications of predicted climate change for insect pests in the UK, with emphasis on non-indigenous species. Glob. Chang. Biol. 1998, 4, 785-796. [CrossRef]

25. Hardwick, N.V. Disease forecasting. In The Epidemiology of Plant Diseases; Cooke, B., Jones, D., Kaye, B., Eds.; Springer: Dordrecht, The Netherlands, 2006; pp. 239-267.

26. Wolfe, D.W.; Ziska, L.; Petzoldt, C.; Seaman, A.; Chase, L.; Hayhoe, K. Projected change in climate thresholds in the Northeastern US: Implications for crops, pests, livestock, and farmers. Mitig. Adapt. Strateg. Glob. Chang. 2008, 13, 555-575. [CrossRef]

27. Dixon, J.; Cobb, A.H.; Sanders, G.E. Possible herbicide: Ozone pollution interactions in United Kingdom crops. In Proceedings of the Brighton Crop Protection Conference, Weeds, Brighton, UK, 22-25 November 1993.

28. Juroszek, P.; Von Tiedemann, A. Potential strategies and future requirements for plant disease management under a changing climate. Plant Pathol. 2011, 60, 100-112. [CrossRef]

29. Juroszek, P.; Von Tiedemann, A. Plant pathogens, insect pests and weeds in a changing global climate: A review of approaches, challenges, research gaps, key studies and concepts. J. Agric. Sci. 2013, 151, 163-188. [CrossRef]

30. Harvell, C.D.; Mitchell, C.E.; Ward, J.R.; Altizer, S.; Dobson, A.P.; Ostfeld, R.S.; Samuel, M.D. Climate warming and disease risks for terrestrial and marine biota. Science 2002, 296, 2158-2162. [CrossRef]

31. Brasier, C.M. Phytophthora cinnamomi and oak decline in southern Europe. Environmental constraints including climate change. Ann. Des Sci. For. 1996, 53, 347-358. [CrossRef]

32. Coakley, S.M.; Scherm, H.; Chakraborty, S. Climate change and plant disease management. Annu. Rev. Phytopathol. 1999, 37, 399-426. [CrossRef]

33. Shakhramanyan, N.G.; Schneider, U.A.; McCarl, B.A. US agricultural sector analysis on pesticide externalities-The impact of climate change and a Pigovian tax. Clim. Chang. 2013, 117, 711-723. [CrossRef]

34. Just, R.E.; Pope, R.D. Production function estimation and related risk considerations. Am. J. Agric. Econ. 1979, 61, 276-284. [CrossRef]

35. McCarl, B.A.; Rettig, R.B. Influence of hatchery smolt releases on adult salmon production and its variability. Can. J. Fish. Aquat. Sci. 1983, 40, 1880-1886. [CrossRef]

36. Chen, C.C.; McCarl, B.A.; Schimmelpfennig, D.E. Yield variability as influenced by climate: A statistical investigation. Clim. Chang. 2004, 66, 239-261. [CrossRef]

37. Blanc, E.; Schlenker, W. The use of panel models in assessments of climate impacts on agriculture. Rev. Environ. Econ. Policy 2017, 11, 258-279. [CrossRef]

38. Buccola, S.T.; McCarl, B.A. Small-sample evaluation of mean-variance production function estimators. Am. J. Agric. Econ. 1986, 68, 732-738. [CrossRef]

39. USDA/NASS QuickStats Ad-Hoc Query Tool. Available online: https://quickstats.nass.usda.gov/ (accessed on 15 June 2018).

40. NOAA Data Access. Available online: https://www.ncdc.noaa.gov/data-access (accessed on 27 June 2018).

41. Wollenweber, B.; Porter, J.R.; Schellberg, J. Lack of interaction between extreme high-temperature events at vegetative and reproductive growth stages in wheat. J. Agron. Crop Sci. 2003, 189, 142-150. [CrossRef]

42. Lasram, S.; Oueslati, S.; Valero, A.; Marin, S.; Ghorbel, A.; Sanchis, V. Water activity and temperature effects on fungal growth and ochratoxin A production by ochratoxigenic Aspergillus carbonarius isolated from Tunisian grapes. J. Food Sci. 2010, 75, M89-M97. [CrossRef]

43. Mayo, Z.B. Influences of rainfall and sprinkler irrigation on the residual activity of insecticides applied to corn for control of adult western corn rootworm (Coleoptera: Chrysomelidae). J. Econ. Entomol. 1984, 77, 190-193. [CrossRef]

(C) 2020 by the authors. Licensee MDPI, Basel, Switzerland. This article is an open access article distributed under the terms and conditions of the Creative Commons Attribution (CC BY) license (http://creativecommons.org/licenses/by/4.0/). 